\title{
Identifying the origin and geochemical evolution of groundwater using hydrochemistry and stable isotopes in the Subei Lake basin, Ordos energy base, Northwestern China
}

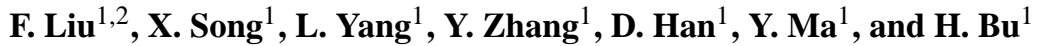 \\ ${ }^{1}$ Key Laboratory of Water Cycle and Related Land Surface Processes, Institute of Geographic Sciences and Natural \\ Resources Research, Chinese Academy of Sciences, 11 A, Datun Road, Chaoyang District, Beijing, 100101, China \\ ${ }^{2}$ University of Chinese Academy of Sciences, Beijing, 100049, China
}

Correspondence to: X. Song (songxf@igsnrr.ac.cn)

Received: 12 March 2014 - Published in Hydrol. Earth Syst. Sci. Discuss.: 28 May 2014

Revised: 17 October 2014 - Accepted: 17 December 2014 - Published: 28 January 2015

\begin{abstract}
A series of changes in groundwater systems caused by groundwater exploitation in energy base have been of great concern to hydrogeologists. The research aims to identify the origin and geochemical evolution of groundwater in the Subei Lake basin under the influence of human activities. Water samples were collected, and major ions and stable isotopes $\left(\delta^{18} \mathrm{O}, \delta \mathrm{D}\right)$ were analyzed. In terms of hydrogeological conditions and the analytical results of hydrochemical data, groundwater can be classified into three types: the Quaternary groundwater, the shallow Cretaceous groundwater and the deep Cretaceous groundwater. Piper diagram and correlation analysis were used to reveal the hydrochemical characteristics of water resources. The dominant water type of the lake water was Cl-Na type, which was in accordance with hydrochemical characteristics of inland salt lakes; the predominant hydrochemical types for groundwater were $\mathrm{HCO}_{3}-\mathrm{Ca}, \mathrm{HCO}_{3}-\mathrm{Na}$ and mixed $\mathrm{HCO}_{3}-\mathrm{Ca}-\mathrm{Na}-\mathrm{Mg}$ types. The groundwater chemistry is mainly controlled by dissolution/precipitation of anhydrite, gypsum, halite and calcite. The dedolomitization and cation exchange are also important factors. Rock weathering is confirmed to play a leading role in the mechanisms responsible for the chemical composition of groundwater. The stable isotopic values of oxygen and hydrogen in groundwater are close to the local meteoric water line, indicating that groundwater is of modern local meteoric origin. Unlike significant differences in isotopic values between shallow groundwater and deep groundwater in the Habor Lake basin, shallow Cretaceous groundwater and deep Cretaceous groundwater have similar isotopic characteristics
\end{abstract}

in the Subei Lake basin. Due to the evaporation effect and dry climatic conditions, heavy isotopes are more enriched in lake water than in groundwater. The low slope of the regression line of $\delta^{18} \mathrm{O}$ and $\delta \mathrm{D}$ in lake water could be ascribed to a combination of mixing and evaporation under conditions of low humidity. Comparison of the regression line for $\delta^{18} \mathrm{O}$ and $\delta \mathrm{D}$ showed that lake water in the Subei Lake basin contains more heavily isotopic composition than that in the Habor Lake basin, indicating that lake water in the discharge area has undergone stronger evaporation than lake water in the recharge area. Hydrochemical and isotopic information of utmost importance has been provided to decision makers by the present study so that a sustainable groundwater management strategy can be designed for the Ordos energy base.

\section{Introduction}

The Ordos Basin is located in Northwestern China, which covers an area of $28.2 \times 10^{4} \mathrm{~km}^{2}$ in total and comprises the second largest coal reserves in China (Dai et al., 2006). It was authorized as a national energy base in 1998 by the former State Planning Commission (Hou et al., 2006). More than 400 lake basins with diverse sizes are distributed in the Ordos Basin. The Dongsheng-Shenfu coalfield, situated in the Inner Mongolia Autonomous Region, is an important component of the Ordos energy base. It is the largest explored coalfield with enormous potential for future development. The proven reserves of coal are 230 billion tons. The coal is ex- 
tracted from Jurassic strata and subsurface mining is common. Local residents there mostly depend on groundwater on account of the serious shortage of surface water. Water resources support the exploitation of coal and development of related industries. In China, since 2011, all new construction projects must carry out an environment evaluation of groundwater consistent with the technical guidelines of the PRC Ministry of Environmental Protection (2011). It is of greatest significance in mining areas, because water resources are an essential component of the mining process (Agartan and Yazicigil, 2012). Over the past several decades, the quantity and quality of groundwater resources have been affected by the rapid development of coal mining. Haolebaoji well field of Subei Lake basin is a typical, large well field and acts as an important water source for this coalfield. However, largescale and intensive groundwater exploitation could remarkably influence the hydrochemical field of groundwater systems in the study area. In recent years, with the fast development of Ordos energy base, more and more well fields have been built in some lake basins (including Haolebaoji well field newly built in the Subei Lake basin) in order to meet the increasing demand on water resources. However, due to a lack of adequate hydrogeological knowledge about these specific lake basins and reasonable groundwater management strategies, water resources in these specific lake basins are currently subject to increasing pressure from altered hydrology associated with water extraction for regional development and groundwater over-exploitation has taken place. If it continues, it may cause a series of negative impacts on the groundwater-dependent ecosystem around these lakes. Thus, studies about the lake basins are urgently needed so as to obtain comprehensive knowledge of the hydrochemical and isotopic characteristics, and geochemical evolution of groundwater under the background of intensive groundwater exploitation.

Research of groundwater and hydrogeology in the Ordos Basin has been conducted by numerous Chinese scholars and institutes because the Ordos Basin plays a vital role in natural resources exploitation and national economic development. Most importantly, China Geological Survey Bureau has conducted some regional-scale research on groundwater resources of Ordos Basin beginning in 1980s (Zhang et al., 1986; Hou et al., 2008). The previous research has clarified geology and hydrogeology and has provided a comprehensive overview of quantity and quality of groundwater in this region, laying a solid foundation for the present study. However, regional-scale groundwater investigations may not provide much accurate information on the groundwater flow characteristics in small basins (Toth, 1963). Hence, it is also significant to implement local groundwater resource investigations. As Winter (1999) concluded that lakes in different part of groundwater flow systems have different flow characteristics. Data on hydrochemistry and stable isotopes of water were used to study the origin and geochemical evolution of groundwater in the Habor Lake basin (Yin et al.,
2009), which is located in the recharge zone. But other lakes in the runoff and discharge area still have not been studied so far. Due to the particularity of the discharge area, a variety of hydrochemical effects such as evaporation, decarbonation, strong mixing action, etc., take place and result in extremely complicated hydrochemical and isotopic characteristics. In addition, intensive groundwater withdrawal has dramatically changed the local hydrologic cycle in these specific lake basins, groundwater flow field and hydrochemistry have been changed significantly, and a series of ecological environment problems have taken place. Therefore, given that these potential problems originate from human activity, it is essential to conduct hydrochemical and isotopic study of Subei Lake basin located in the discharge area.

Isotopic and geochemical indicators often serve as effective methods for solving multiple problems in hydrology and hydrogeology, especially in semi-arid and arid regions (Clark and Fritz, 1997; Cook and Herczeg, 1999). These techniques have been widely used to obtain groundwater information such as its source, recharge and the interaction between groundwater and surface water (De Vries and Simmers, 2002; Yuko et al., 2002; Yang et al., 2012a). The technique of stable isotopes as excellent tracers has been widely used by many scholars in the study of hydrological cycle (Chen et al., 2011; Cervi et al., 2012; Garvelmann et al., 2012; Yang et al., 2012a; Hamed and Dhahri, 2013; Kamdee et al., 2013). Greater knowledge on the origin and behavior of major ions in groundwater can enhance the understanding of the geochemical evolution of groundwater. Measurement of the relative concentration of major ions in groundwater from different aquifers can provide information on the geochemical reactions within the aquifer and the possible evolutionary pathways of groundwater (Cook and Herczeg, 1999).

The aim of the research is to recognize the origin and geochemical evolution of groundwater in the Subei Lake basin under the influence of human activities. The main objectives are to (1) ascertain the origin of groundwater and (2) determine the geochemical factors and mechanisms controlling the chemical composition of groundwater. In the context of a large number of well fields built in some lake basins in order to meet the increasing demand of water resources, the results of the present study will be valuable in obtaining a deeper insight into hydrogeochemical changes caused by human activity, and providing significant information on, for example, the water quality situation and geochemical evolution of groundwater to decision makers so that they can make sustainable groundwater management strategies for other similar small lake basins and even the Ordos energy base. 


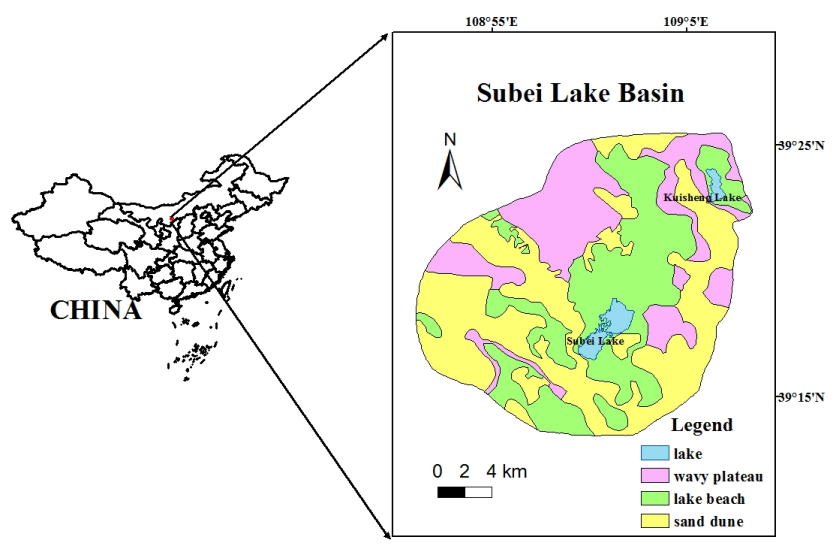

Figure 1. Location of the study area and geomorphic map.

\section{Study area}

\subsection{Physiography}

The study area is situated in the northern part of the Ordos Basin, which is located at the junction of Uxin Banner, Hanggin Banner and Ejin Horo Banner in Ordos City and is mainly administratively governed by Uxin Banner of Ordos City. It covers an area of almost $400 \mathrm{~km}^{2}$ within $39^{\circ} 13^{\prime} 30^{\prime \prime}-39^{\circ} 25^{\prime} 40^{\prime \prime} \mathrm{N}$ and $108^{\circ} 51^{\prime} 24^{\prime \prime}-109^{\circ} 08^{\prime} 40^{\prime \prime} \mathrm{E}$. Its length is $23 \mathrm{~km}$ from east to west and its width is $22 \mathrm{~km}$ from north to south (Fig. 1).

The continental semi-arid to arid climate controls the whole study area, which is characterized by long, cold winters and short, hot summers (Li et al., 2010, 2011). According to the data of the Wushenzhao meteorological station, the average monthly temperature ranges from $-11.5^{\circ} \mathrm{C}$ in January to $21.9^{\circ} \mathrm{C}$ in July. The mean annual precipitation in the study area was $324.3 \mathrm{~mm} \mathrm{yr}^{-1}$ from 1985 to 2008 . The total annual precipitation varied greatly from year to year with a minimum of $150.2 \mathrm{~mm}$ in 2000 and a maximum of $432.3 \mathrm{~mm}$ in 1985. The majority of the precipitation falls in the form of rain during the 3-month period from June to August, with more than $63.6 \%$ of annual precipitation (Fig. 2). The mean annual evaporation is $2349.1 \mathrm{~mm} \mathrm{yr}^{-1}$ (from 1985 to 2008) at Wushenzhao station (Fig. 2), which far exceeds rainfall for the area. The average value of monthly evaporation is lowest in January (42.4 $\mathrm{mm} \mathrm{month}^{-1}$ ) and highest from May to July, with maximum evaporation in May $\left(377.4 \mathrm{~mm} \mathrm{month}^{-1}\right)$.

As a small-scale lake basin, the general geomorphic types of Subei Lake basin are wavy plateau, lake beach and sand dunes (Fig. 1). The terrain of Subei Lake's west, east and north sides is relatively higher with altitudes between 1370 and $1415 \mathrm{~m}$; the terrain of its south side is slightly lower with elevations between 1290 and $1300 \mathrm{~m}$. The topography of the center area of Subei Lake basin is flat and low-lying. There are no perennial or ephemeral rivers within the study area; the main surface water bodies are Subei and Kuisheng

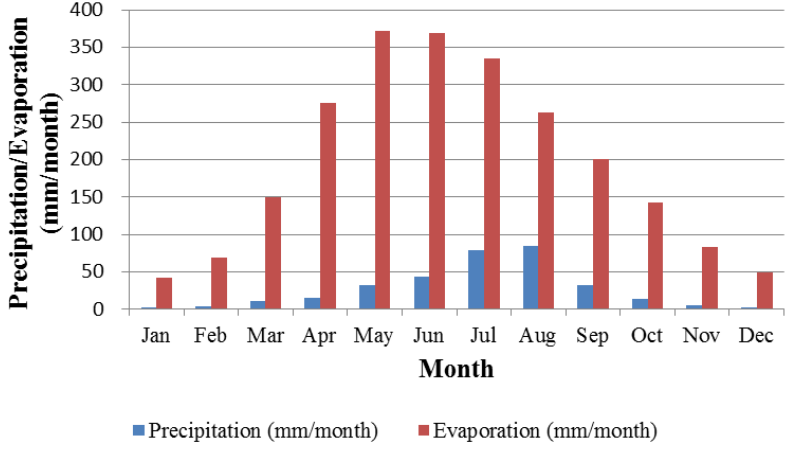

Figure 2. Average monthly precipitation and evaporation in the study area.

lakes, and they are situated in the same watershed considering actual hydrogeological conditions and groundwater flow field. In response to precipitation, diffuse overland flow and groundwater recharge the Subei and Kuisheng lakes (Hou et al., 2006; Wang et al., 2010). Subei Lake is located in the low-lying center of the study area (Fig. 1), which is an inland lake characterized by high alkalinity; Kuisheng Lake is also a perennial water body and it is located in northeastern corner of the study area, only covering $2 \mathrm{~km}^{2}$ (Fig. 1).

\subsection{Geologic and hydrogeologic setting}

Subei Lake basin is a relatively closed hydrogeological unit given that a small quantity of lateral outflow occurs in a small part of southern boundary (Wang et al., 2010). The Quaternary sediments and Cretaceous formation can be observed in the study area. The Quaternary sediments are mainly distributed around the Subei Lake with relatively smaller thickness. Generally the thickness of Quaternary sediments is below $20 \mathrm{~m}$. The Quaternary layer is chiefly composed of the interlaced layers of sand and mud. The Cretaceous formations mainly consist of sedimentary sandstones and generally outcrop in the regions with relatively higher elevation. The maximum thickness of Cretaceous rocks could be nearly $1000 \mathrm{~m}$ in the Ordos Plateau (Yin et al., 2009), so the Cretaceous formation composed of mainly sandstone is the major water-supplying aquifer of the investigated area. Calcite, dolomite, anhydrite, aragonite, gypsum, halite and feldspar are major minerals in the Quaternary and Cretaceous strata (Hou et al., 2006).

Groundwater resources are very abundant in the investigated area, and phreatic aquifer and confined aquifer can be observed in this region. According to Wang et al. (2010) and the data from Inner Mongolia Second Hydrogeology Engineering Geological Prospecting Institute, the phreatic aquifer is composed of Quaternary and Cretaceous sandstones, with its thickness ranging from 10.52 to $63.54 \mathrm{~m}$. In terms of borehole data, the similar groundwater levels in the Quaternary and Cretaceous phreatic aquifers indicate a very close hy- 


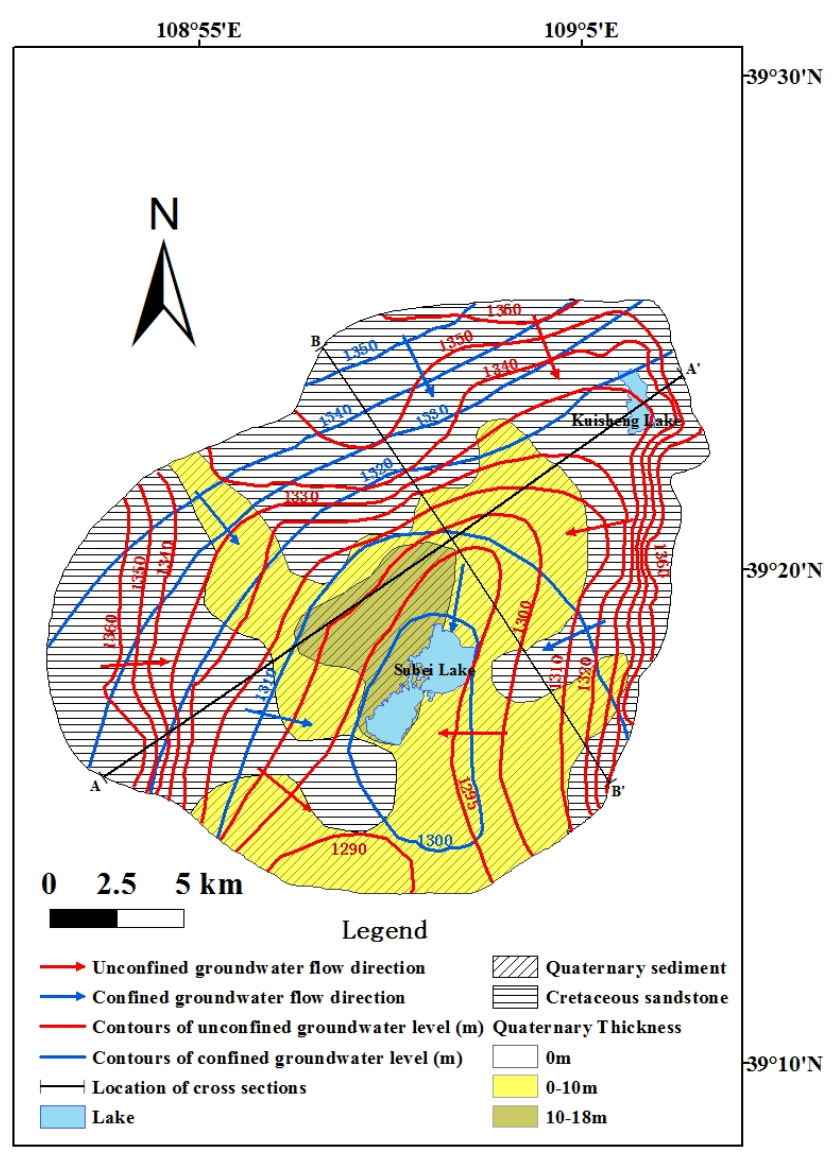

Figure 3. Hydrogeological map of the study area. Data were revised from original source (Inner Mongolia Second Hydrogeology Engineering Geological Prospecting Institute, 2010).

draulic connection between the Quaternary layer and Cretaceous phreatic aquifer, which could be viewed as an integrated unconfined aquifer in the area. The depth to water table in unconfined aquifer is influenced by the terrain change, of which the minimum value is below $1 \mathrm{~m}$ in the low-lying region, and the maximum value could be up to $13.24 \mathrm{~m}$. The hydraulic conductivity of the aquifer changes between 0.16 and $17.86 \mathrm{~m} \mathrm{day}^{-1}$. The specific yield of unconfined aquifer varies from 0.058 to 0.155 . The recharge source of groundwater in the unconfined aquifer is mainly the infiltration recharge of precipitation; it can be also recharged by lateral inflow from groundwater outside the study area. Besides the above recharge terms, leakage recharge from the underlying confined aquifer and infiltration recharge of irrigation water can also provide a small percentage of groundwater recharge. Evaporation is the main discharge way of the unconfined groundwater. In addition, lateral outflow, artificial exploitation and leakage discharge are also included in the main discharge patterns. Unconfined groundwater levels were contoured to illustrate the general flow field in the area (Fig. 3). Groundwater levels were monitored during September 2003.
As is shown in Fig. 3, lateral outflow occurs in a small part of southern boundary determined by analyzing the contours and flow direction of groundwater. The groundwater flows predominantly from surrounding uplands to low lands, which is under the control of topography. On the whole, groundwater in phreatic aquifer flows toward Subei Lake and recharges lake water (Fig. 3).

The unconfined and confined aquifers are separated by an uncontinuous aquitard. Generally speaking, permeable layers and aquitards intervein in the vertical profile of the aquifer system. Nevertheless, aquitards may pinch out in many places, so the aquifer system acts as a single hydrogeologic unit. In the present study, the covering aquitard is composed of the mudstone layer, which is mainly distributed in the second sand layer, and discontinued mudstone lens could also be observed in Cretaceous strata (Fig. 4). The phreatic aquifer is underlain by a confined aquifer composed of Cretaceous rocks. Due to huge thickness and high permeability of confined aquifer, it is regarded as the most promising water-supplying aquifer for domestic and industrial uses. The hydraulic conductivity of confined aquifer changes between 0.14 and $27.04 \mathrm{~m} \mathrm{day}^{-1}$. The hydraulic gradient varies from 0.0010 to 0.0045 and the storage coefficient changes between $2.17 \times 10^{-5}$ and $1.98 \times 10^{-3}$. The confined aquifer primarily receives leakage recharge from the unconfined groundwater. The flow direction of confined groundwater is similar to that of unconfined groundwater (Fig. 3). Artificial exploitation is the major way in which confined groundwater is drained.

In the present study, the depth of sampling wells, in combination with hydrogeological map of the study area, is used to classify the groundwater as Quaternary groundwater, shallow Cretaceous groundwater and deep Cretaceous groundwater. As a research on an adjacent, specific, shallow groundwater system of Ordos Basin shows that the circulation depth is $120 \mathrm{~m}$ (Yin et al., 2009). It is difficult to determine the circulation depth of shallow groundwater in fact because the circulation depth of local flow systems changes depending on the topography and the permeability of local systems (Yin et al., 2009). In this study, Quaternary groundwater was defined on the basis of the distribution of Quaternary sediments thickness and depth of sampling wells. According to Hou et al. (2006), the maximum circulation depth of local groundwater flow system in the study area is also $120 \mathrm{~m}$, determined by using a large amount of hydrochemical and isotopic data; $120 \mathrm{~m}$ is chosen as the maximum circulation depth of the local groundwater system and is used to divide the Cretaceous groundwater samples into two groups: samples taken in wells shallower than $120 \mathrm{~m}$ were classified as shallow Cretaceous groundwater, while samples taken in wells deeper than $120 \mathrm{~m}$ were deep Cretaceous groundwater. 

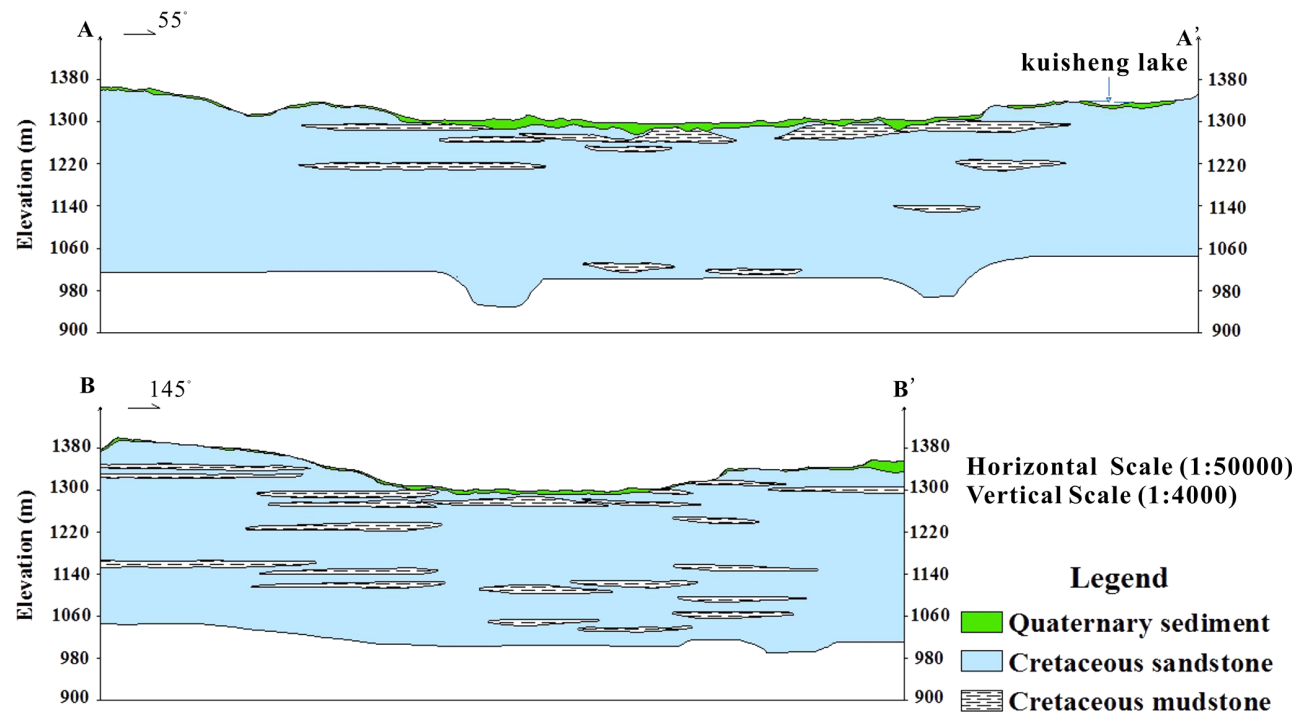

Figure 4. Geologic sections of the study area. Data were revised from original source (Inner Mongolia Second Hydrogeology Engineering Geological Prospecting Institute, 2010).

\section{Methods}

\subsection{Water sampling}

Two important sampling actions were conducted in the study area during August and December 2013, respectively. A total of 95 groundwater samples and seven lake water samples were collected. The first sampling action was during the rainy season and the other was during the dry season. The sampling locations are shown in Fig. 5. The water samples were taken from wells for domestic and agricultural purposes, ranging in depth from 2 to $300 \mathrm{~m}$. The length of screen pipes in all sampling wells ranges from 1 to $10 \mathrm{~m}$ and every sampling well has only one screen pipe rather than multiple screens. The distance between the bottom of the screen pipe and the total well depth ranges from 0 to $3 \mathrm{~m}$ in the study area, and the bottom depth of screen pipe was assigned to the water samples. The samples from the wells were mostly taken using pumps installed in these wells and after removing several well volumes prior to sampling. The 100 and $50 \mathrm{~mL}$ polyethylene bottles were pre-rinsed with water sample three times before the final water sample was collected. Lake water samples were collected at Subei Lake, Kuisheng Lake and Shahaizi Lake. Cellulose membrane filters $(0.45 \mu \mathrm{m})$ were used to filter samples for cation and anion analysis. All samples were sealed with adhesive tape so as to prevent evaporation. GPS was applied to locate the sampling locations.

\subsection{Analytical techniques}

Electrical conductivity (EC), $\mathrm{pH}$ value and water temperature of each sample were measured in situ using an $\mathrm{EC} / \mathrm{pH}$ meter (WM-22EP, DKK-TOA, Japan), which was previously calibrated. Dissolved oxygen concentration and oxidationreduction potential were also determined using a $\mathrm{HACH}$ HQ30d Single-Input Multi-Parameter Digital Meter. In situ hydrochemical parameters were monitored until these values reached a steady state.

The hydrochemical parameters were analyzed at the Center for Physical and Chemical Analysis of Institute of Geographic Sciences and Natural Resources Research, Chinese Academy of Sciences (IGSNRR, CAS). Major ion compositions were measured for each sample including $\mathrm{K}^{+}, \mathrm{Na}^{+}$, $\mathrm{Ca}^{2+}, \mathrm{Mg}^{2+}, \mathrm{Cl}^{-}, \mathrm{SO}_{4}^{2-}$ and $\mathrm{NO}_{3}^{-}$. An inductively coupled plasma optical emission spectrometer (ICP-OES) (PerkinElmer Optima 5300DV, USA) was applied to analyze major cations. Major anions were measured by ion chromatography (ICS-2100, Dionex, USA). $\mathrm{HCO}_{3}^{-}$concentrations in all groundwater samples were determined by the titration method using $0.0048 \mathrm{M} \mathrm{H}_{2} \mathrm{SO}_{4}$ on the day of sampling; methyl orange endpoint titration was adopted with the final $\mathrm{pH}$ of 4.2-4.4. Due to the extremely high alkalinity of lake water samples, $\mathrm{HCO}_{3}^{-}$concentrations in all lake water samples were analyzed by titration using $0.1667 \mathrm{M} \mathrm{H}_{2} \mathrm{SO}_{4}$. $\mathrm{CO}_{3}^{2-}$ concentrations were also analyzed by titration; phenolphthalein was used as an indicator of endpoint titration.

Hydrogen $(\delta \mathrm{D})$ and oxygen $\left(\delta^{18} \mathrm{O}\right)$ composition in the water samples were analyzed using a liquid water isotope analyzer (LGR, USA) at the Institute of Geographic Sciences and Natural Resources Research, Chinese Academy of Sciences (IGSNRR, CAS). Results were expressed in the standard $\delta$ notation as per mil (\%o) difference from Vienna standard mean ocean water (VSMOW, $0 \%$ ) with analytical precisions of $\pm 1 \%_{\circ}(\delta \mathrm{D})$ and $\pm 0.1 \%_{\circ}\left(\delta^{18} \mathrm{O}\right)$. 


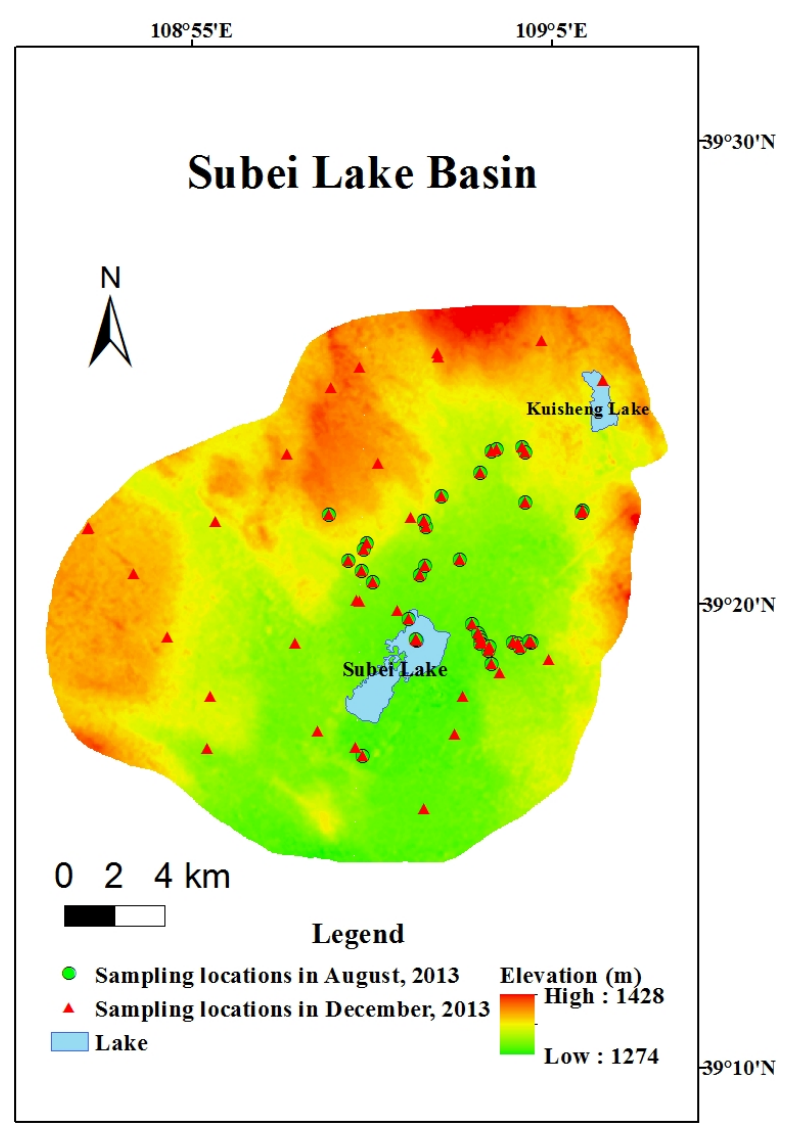

Figure 5. Sampling locations in August and December 2013.

\section{Results}

\subsection{Hydrochemical characteristics}

In situ water quality parameters such as $\mathrm{pH}$, electrical conductivity (EC), temperature, dissolved oxygen concentration (DO), oxidation-reduction potential (ORP) and total dissolved solids (TDS) as well as analytical data of the major ions composition in groundwater and lake water samples are shown in Table 1 and Table S1 in the Supplement. Based on the chemical data, hydrochemical characteristics of groundwater and lake water are discussed.

The chemical composition for lake water showed that $\mathrm{Na}^{+}$ accounted for, on average, $93 \%$ of total cations and $\mathrm{Cl}^{-}$accounted for, on average, $58 \%$ of total anions. Thus, $\mathrm{Na}^{+}$and $\mathrm{Cl}^{-}$were the dominant elements (Fig. 6), which was in accordance with hydrochemical characteristics of inland salt lakes. This was also observed in lake water of Habor Lake basin located in the recharge area (Yin et al., 2009). The $\mathrm{pH}$ of lake water varied from 8.86 to 10.25 with an average of 9.74 in August and from 8.49 to 10.47 with an average of 9.23 in December; it can be seen that the $\mathrm{pH}$ was relatively stable and was always more than 8.4 without obvious seasonal variation, which indicated that the dissolved carbon-

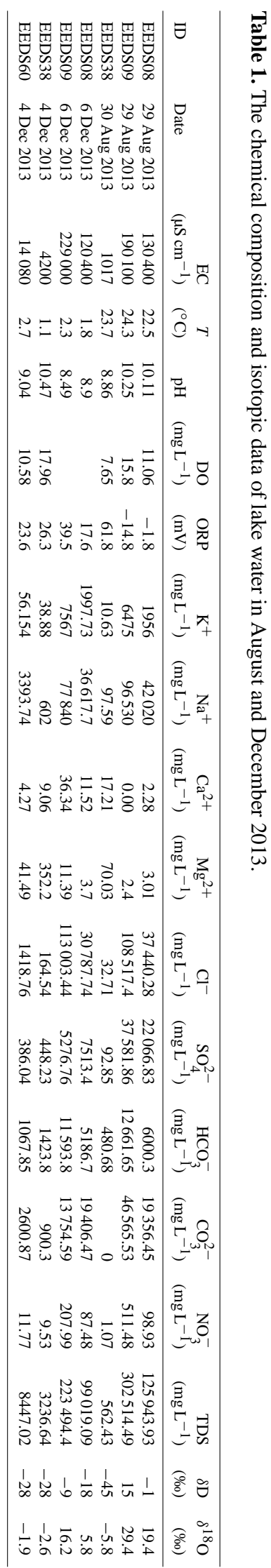




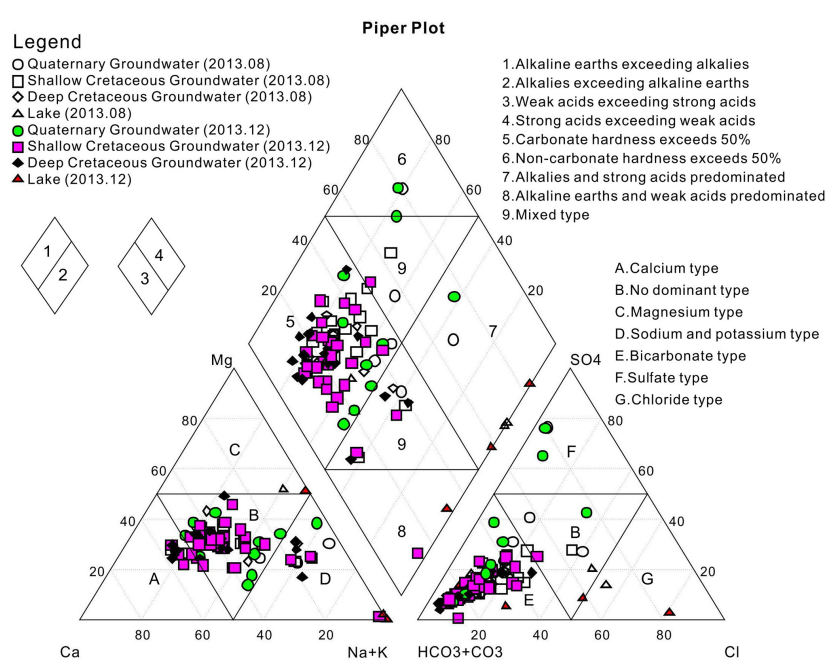

Figure 6. Piper diagram of groundwater and lake water in August and December 2013.

ates were in the $\mathrm{HCO}_{3}^{-}$and $\mathrm{CO}_{3}^{2-}$ forms simultaneously. The temperatures of lake water ranged from 1.1 to $24.3^{\circ} \mathrm{C}$ with large seasonal variations, implying that the surface water body was mainly influenced by hydrometeorological factors. The dissolved oxygen concentration of lake water showed an upward tendency from August (mean value: $11.50 \mathrm{mg} \mathrm{L}^{-1}$ ) to December (mean value: $14.27 \mathrm{mg} \mathrm{L}^{-1}$ ) because the relationship between water temperature and DO is inverse when oxygen content in the air stays relatively stable. With the decreasing water temperature, the dissolved oxygen value rises. The average value of ORP ranged from $15.1 \mathrm{mV}$ in August to $26.8 \mathrm{mV}$ in December, which was in accordance with the upward tendency of DO. It showed that lake water had stronger oxidation in December than that in August and there is a close relationship between DO and ORP. The average values of major ions concentrations showed a downward trend except for $\mathrm{Ca}^{2+}, \mathrm{Mg}^{2+}$ from August to December. Specifically, the average values of $\mathrm{Ca}^{2+}$ and $\mathrm{Mg}^{2+}$ increased from 6.50 to $15.30 \mathrm{mg} \mathrm{L}^{-1}$ and 25.15 to $102.20 \mathrm{mg} \mathrm{L}^{-1}$, respectively; other ions concentrations were reduced to different degrees. The same variation trend of major ions from $\mathrm{Au}-$ gust to December could be found in the Habor Lake basin (Yin et al., 2009) as well. Before August, the strong evaporation capacity of lake water exceeded the finite recharge amount, which caused lake water to be enriched. After August, lake water was recharged and diluted by groundwater and a large amount of fresh overland flow from precipitation. The EC values varied between 1017 and $229000 \mu \mathrm{S} \mathrm{cm}^{-1}$. This relatively large range of variation was closely related to the oscillation of the TDS values, which ranged from 0.56 to $302.5 \mathrm{~g} \mathrm{~L}^{-1}$. The results showed that lake water chemistry was controlled by strong evaporation and recharge from overland flow and groundwater.
The hydrochemical data of groundwater were plotted on a Piper triangular diagram (Piper, 1953), which is perhaps the most commonly used method for identifying hydrochemical patterns of major ion composition (Fig. 6). With respect to cations, most of samples are scattered in zones A, B and D of the lower-left triangle, indicating that some are calciumtype, some are sodium-type water but most are of a mixed type; regarding anions, most groundwater samples are plotted in zone $\mathrm{E}$ of the lower-right triangle (Fig. 6), showing that bicarbonate-type water is predominant. The predominant hydrochemical types are $\mathrm{HCO}_{3}-\mathrm{Ca}, \mathrm{HCO}_{3}-\mathrm{Na}$ and mixed $\mathrm{HCO}_{3}-\mathrm{Ca}-\mathrm{Na}-\mathrm{Mg}$ types. Figure 6 also indicates that there are three groups of groundwater in the Subei Lake basin: the Quaternary groundwater, shallow Cretaceous groundwater and deep Cretaceous groundwater. The shallow Cretaceous groundwater refers to groundwater in the local groundwater system, and the deep Cretaceous groundwater refers to groundwater in the intermediate groundwater system of Ordos Basin. The hydrochemical characteristics of the three groups of groundwater indicate that they have undergone different degrees of mineralization.

With respect to the Quaternary groundwater, the $\mathrm{pH}$ varied from 7.64 to 9.04 with an average of 8.09 in August and changed from 7.49 to 9.26 with an average of 8.08 in December, indicating an alkaline nature. The TDS varied from 396 to $1202 \mathrm{mg} \mathrm{L}^{-1}, 314$ to $1108 \mathrm{mg} \mathrm{L}^{-1}$ with averages of 677 and $625 \mathrm{mg} \mathrm{L}^{-1}$, respectively, in August and December. The major cations were $\mathrm{Na}^{+}, \mathrm{Ca}^{2+}$ and $\mathrm{Mg}^{2+}$, while the major anions were $\mathrm{HCO}_{3}^{-}$and $\mathrm{SO}_{4}^{2-}$.

As for the shallow Cretaceous groundwater $(<120 \mathrm{~m})$, the $\mathrm{pH}$ varied from 7.37 to 8.3 with an average of 7.77 in $\mathrm{Au}-$ gust and oscillated from 7.49 to 9.37 with an average of 8.14 in December. The TDS varied from 249 to $1383 \mathrm{mg} \mathrm{L}^{-1}$ and from 217 to $1239 \mathrm{mg} \mathrm{L}^{-1}$, with averages of 506 and $400 \mathrm{mg} \mathrm{L}^{-1}$, respectively, in August and December.

For the deep Cretaceous groundwater $(>120 \mathrm{~m})$, the $\mathrm{pH}$ varied from 7.75 to 8.09 with an average of 7.85 in August and fluctuated from 7.99 to 8.82 with an average of 8.23 in December. The TDS varied from 266 to $727 \mathrm{mg} \mathrm{L}^{-1}, 215$ to $464 \mathrm{mg} \mathrm{L}^{-1}$ with averages of 377 and $296 \mathrm{mg} \mathrm{L}^{-1}$, respectively, in August and December.

\subsection{Stable isotopic composition in groundwater and surface water}

In the present study, the results of the stable isotope analysis for groundwater and lake water are plotted in Fig. 7. In a previous study, the local meteoric water line (LMWL) in the northern Ordos Basin had been developed by Yin et al. (2010). The LMWL is $\delta \mathrm{D}=6.45 \delta^{18} \mathrm{O}-6.51\left(r^{2}=0.87\right)$, which is similar to that developed by Hou et al. (2007) $\left(\delta \mathrm{D}=6.35 \delta^{18} \mathrm{O}-4.69\right)$. In addition, it is very clear in the plot that the LMWL is located below the global meteoric water line (GMWL) defined by Craig (1961) $(\delta \mathrm{D}=8$ $\left.\delta^{18} \mathrm{O}+10\right)$, which suggests the occurrence of secondary 


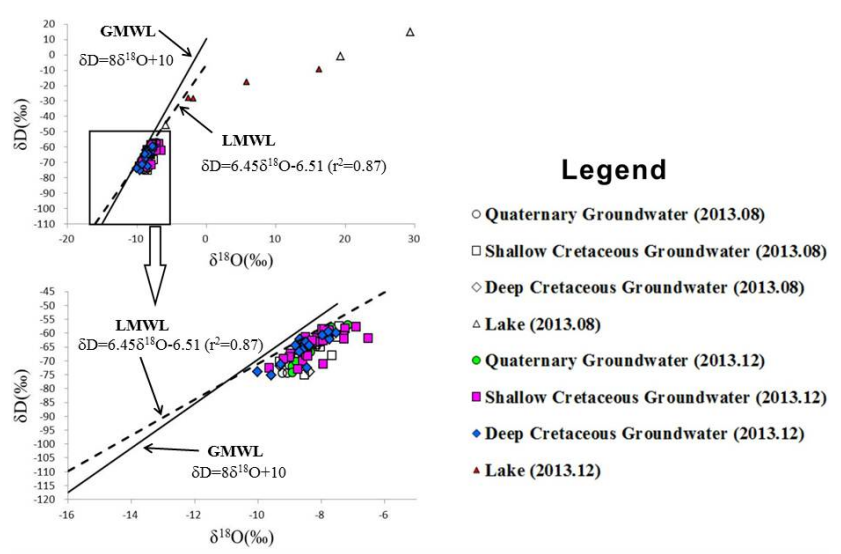

Figure 7. Relationship between hydrogen and oxygen isotopes in groundwater and lake water in August and December 2013.

evaporation during rainfall. The LMWL is controlled by local hydrometeorological factors, including the origin of the vapor mass, re-evaporation during rainfall and the seasonality of precipitation (Clark and Fritz, 1997).

The linear regression curve equation of $\delta^{18} \mathrm{O}$ and $\delta \mathrm{D}$ in groundwater can be defined as $\delta \mathrm{D}=6.3 \delta^{18} \mathrm{O}-13.0\left(r^{2}=\right.$ 0.62 ). Groundwater follows the LMWL in the study area, indicating that it is of modern local meteoric origin rather than the recharge from precipitation in paleoclimate conditions. In August, the stable isotope values in the Quaternary groundwater were found to range from -9.2 to $-8.0 \%$ in ${ }^{18} \mathrm{O}$ with an average of $-8.8 \%$ and from -74 to $-62 \%$ in ${ }^{2} \mathrm{H}$ with an average of $-71 \%$; the shallow Cretaceous groundwater had $\delta^{18} \mathrm{O}$ ranging from -9.3 to $-7.5 \%$ and $\delta \mathrm{D}$ varying from -75 to $-57 \%$. The average values of $\delta^{18} \mathrm{O}$ and $\delta \mathrm{D}$ of the shallow Cretaceous groundwater were -8.3 and $-66 \%$, respectively. $\delta^{18} \mathrm{O}$ and $\delta \mathrm{D}$ of the deep Cretaceous groundwater ranged from -9.3 to $-7.8 \%$ and from -74 to $-61 \%$, respectively. The average values of $\delta^{18} \mathrm{O}$ and $\delta \mathrm{D}$ were -8.4 and $-67 \%$, respectively. In December, the stable isotope values in the Quaternary groundwater ranged from -8.9 to $-7.2 \%$ o in ${ }^{18} \mathrm{O}$ with an average of $-8.2 \%$ and from -74 to $-57 \%$ o in ${ }^{2} \mathrm{H}$ with an average of $-65 \%$; $\delta^{18} \mathrm{O}$ and $\delta \mathrm{D}$ of the shallow Cretaceous groundwater ranged from -9.7 to $-6.5 \%$ o and from -73 to $-58 \%$, respectively. The average values of $\delta^{18} \mathrm{O}$ and $\delta \mathrm{D}$ were -8.2 and $-64 \%$ o, respectively. $\delta^{18} \mathrm{O}$ of the deep Cretaceous groundwater varied from -10.0 to $-7.5 \%$ and $\delta \mathrm{D}$ ranged from -75 to $-60 \%$. The average values of $\delta^{18} \mathrm{O}$ and $\delta \mathrm{D}$ of the deep Cretaceous groundwater were -8.5 and $-66 \%$, respectively.

The regression curve equation of $\delta^{18} \mathrm{O}$ and $\delta \mathrm{D}$ in lake water could be defined as $\delta \mathrm{D}=1.47 \delta^{18} \mathrm{O}-29.09\left(r^{2}=0.95\right)$, where $\delta^{18} \mathrm{O}$ ranged from -5.8 to $29.4 \%$ and $\delta \mathrm{D}$ ranged from -46 to $15 \%$ with averages of 14.3 and $-10 \%$ in August, while in December, $\delta^{18} \mathrm{O}$ and $\delta \mathrm{D}$ of lake water ranged from -2.6 to $16.2 \%$ and from -28 to $-9 \%$, respectively. The average values of $\delta^{18} \mathrm{O}$ and $\delta \mathrm{D}$ were 4.4 and $-21 \%$, respec- tively, in December. The low slope of the regression line of $\delta^{18} \mathrm{O}$ and $\delta \mathrm{D}$ in lake water could be ascribed to a combination of mixing and evaporation under conditions of low humidity.

\subsection{Linkage among geochemical parameters of groundwater}

Correlations among groundwater-quality parameters are shown in Table 2 and Fig. 8. All of the major cations and anions are significantly correlated with TDS (Table 2), which shows that these ions have been dissolved into groundwater continuously and resulted in the rise of TDS.

As is shown in Table 2, the concentration of $\mathrm{Mg}^{2+}$ is correlated with $\mathrm{HCO}_{3}^{-}$and $\mathrm{SO}_{4}^{2-}$, with correlation coefficients of 0.582 and 0.819 , respectively. The concentration of $\mathrm{Ca}^{2+}$ is well correlated with $\mathrm{SO}_{4}^{2-}$ with a correlation coefficient of 0.665 . $\mathrm{Cl}^{-}$has good correlation with $\mathrm{Na}^{+}$with a large correlation coefficient of 0.824 .

The results of linear regression analysis of some pairs of ions are displayed in Fig. 8. There is good correlation between $\mathrm{Cl}^{-}$and $\mathrm{Na}^{+}$in Quaternary groundwater and shallow Cretaceous groundwater; $\mathrm{Ca}^{2+}$ and $\mathrm{SO}_{4}^{2-}$ have a good positive correlation in Quaternary groundwater and shallow Cretaceous groundwater. $\mathrm{Mg}^{2+}$ is well correlated with $\mathrm{HCO}_{3}^{-}$in shallow Cretaceous groundwater.

\section{Discussion}

Generally speaking, water-rock interactions are the most important factors influencing the observed geochemical composition of groundwater (Appelo and Willemsen, 1987); the geochemical and isotopic results of this work are no exception. In terms of dissolved minerals and the correlation of geochemical parameters, the dominant geochemical processes and formation mechanisms could be found (Su et al., 2009). The weathering and dissolution of minerals in the host rocks and ion exchange are generally the main source of ions in groundwater based on available research. The stable isotopes signatures in lake water can reveal the predominant mechanism controlling the chemical composition of lake water.

\subsection{Geochemical processes of groundwater}

As displayed in the correlation analysis of geochemical parameters, a good correlation between $\mathrm{Mg}^{2+}$ and $\mathrm{HCO}_{3}^{-}$indicates that the weathering of dolomite releases ions to the groundwater, as expressed in Reaction (R1). The fact that $\mathrm{Mg}^{2+}$ is well correlated with $\mathrm{HCO}_{3}^{-}$could be found in the Habor Lake basin of Ordos Plateau (Yin et al., 2009). $\mathrm{Ca}^{2+}$ has good correlation with $\mathrm{SO}_{4}^{2-}$, implying that the dissolution of gypsum and anhydrite may be the key processes controlling the chemical composition of groundwater in the discharge area, which can be explained by Reaction (R2). Just as with the achievements obtained by Hou et al. (2006), gyp- 

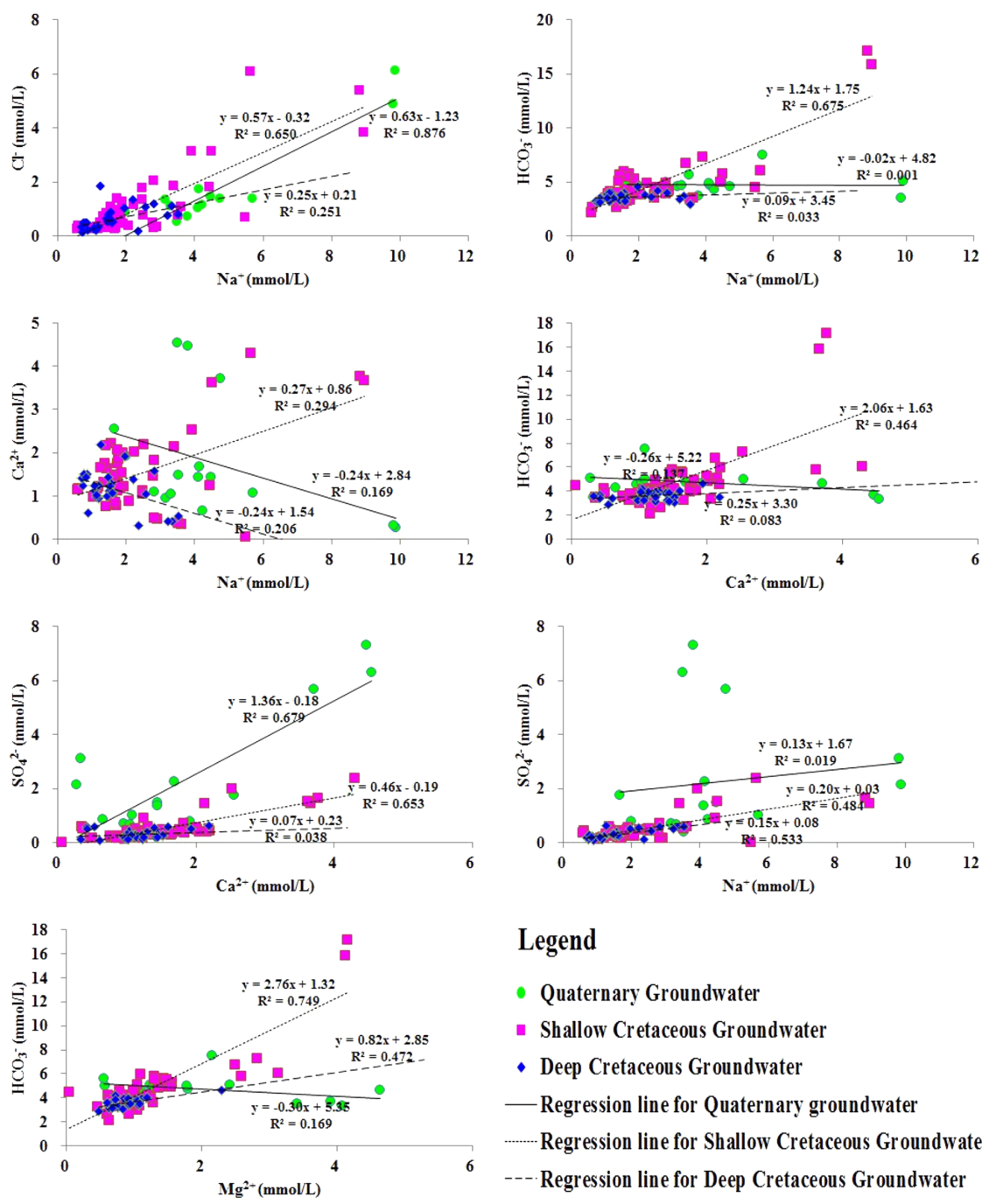

Legend

- Quaternary Groundwater

- Shallow Cretaceous Groundwater

- Deep Cretaceous Groundwater

- Regression line for Quaternary groundwater

-..-...-Regression line for Shallow Cretaceous Groundwater

---Regression line for Deep Cretaceous Groundwater

Figure 8. Relationship between some pairs of ions in groundwater.

sum and anhydrite are present in these strata, so it is reasonable to consider that gypsum and anhydrite are the source of the $\mathrm{SO}_{4}^{2-}$. However, in Yin's study, there is poor correlation between $\mathrm{Ca}^{2+}$ and $\mathrm{SO}_{4}^{2-}$ in the Habor Lake basin (Yin et al., 2009). It can be explained by geochemical evolution of groundwater along flow path from the recharge area to the discharge area. There is poor correlation between $\mathrm{Na}^{+}$ and $\mathrm{SO}_{4}^{2-}$, suggesting that the weathering of Glauber's salt $\left(\mathrm{Na}_{2} \mathrm{SO}_{4} \cdot 10 \mathrm{H}_{2} \mathrm{O}\right)$ may not be the major sources of such ions in groundwater. On the contrary, a good correlation between $\mathrm{Na}^{+}$and $\mathrm{SO}_{4}^{2-}$ can be found in the Habor Lake basin (Yin et al., 2009). It indicates that Glauber's salt may be more abundant in the recharge area (Habor Lake basin) than in the discharge area (Subei Lake basin). Although there is no obvious correlation between $\mathrm{Ca}^{2+}$ and $\mathrm{HCO}_{3}^{-}$, it is reasonable to regard the dissolution of carbonate minerals as a source of $\mathrm{Ca}^{2+}$ and $\mathrm{HCO}_{3}^{-}$due to the widespread occurrence of carbonate rocks in the study area, as conveyed in Reaction (R3).
The concentration of $\mathrm{Mg}^{2+}$ is well correlated with $\mathrm{SO}_{4}^{2-}$, suggesting the possible dissolution of gypsum, followed by cation exchange. The $\mathrm{pH}$ is negatively correlated with $\mathrm{Ca}^{2+}$; it is likely that the dissolution of carbonate minerals is constrained due to the reduction of the hydrogen ion concentration in water at higher $\mathrm{pH}$. It can be judged from the above analysis that during groundwater flow, the following reactions are very likely to take place in the study area:

$\mathrm{CaMg}\left(\mathrm{CO}_{3}\right)_{2}+2 \mathrm{CO}_{2}+2 \mathrm{H}_{2} \mathrm{O} \Leftrightarrow \mathrm{Ca}^{2+}+\mathrm{Mg}^{2+}+4 \mathrm{HCO}_{3}^{-}$,

$\mathrm{CaSO}_{4} \Leftrightarrow \mathrm{Ca}^{2+}+\mathrm{SO}_{4}^{2-}$,

$\mathrm{CaCO}_{3}+\mathrm{CO}_{2}+\mathrm{H}_{2} \mathrm{O} \Leftrightarrow \mathrm{Ca}^{2+}+2 \mathrm{HCO}_{3}^{-}$.

In order to explore the mechanism of salinity in semi-arid regions, the plot of $\mathrm{Na}^{+}$versus $\mathrm{Cl}^{-}$is widely used (Magaritz et 


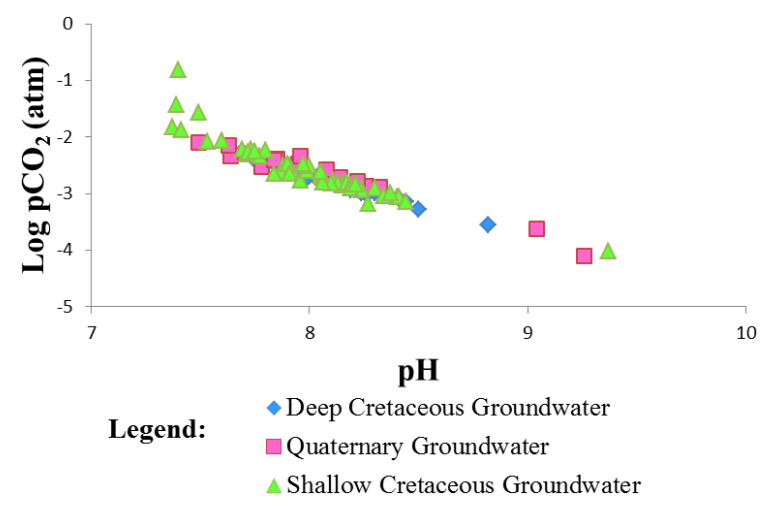

Figure 9. Geochemical relationship of $\mathrm{pH}$ vs. $\log \left(p \mathrm{CO}_{2}\right)$ in groundwater.

al., 1981; Dixon and Chiswell, 1992; Sami, 1992). The concentration of $\mathrm{Cl}^{-}$is well correlated with $\mathrm{Na}^{+}$, suggesting that the dissolution of halite may be the major source of $\mathrm{Na}^{+}$and $\mathrm{Cl}^{-}$. Theoretically, the dissolution of halite will release equal amounts of $\mathrm{Na}^{+}$and $\mathrm{Cl}^{-}$into the solution. Nevertheless, the results deviate from the anticipated $1: 1$ relationship. Almost all samples have more $\mathrm{Na}^{+}$than $\mathrm{Cl}^{-}$. The molar $\mathrm{Na} / \mathrm{Cl}$ ratio varies from 0.68 to 16.00 with an average value of 3.48. A greater $\mathrm{Na} / \mathrm{Cl}$ ratio may be ascribed to the feldspar weathering and the dissolution of other Na-containing minerals. The relatively high $\mathrm{Na}^{+}$concentration in the groundwater could also be illustrated by cation exchange between $\mathrm{Ca}^{2+}$ or $\mathrm{Mg}^{2+}$ and $\mathrm{Na}^{+}$, as is discussed later.

The partial pressure of carbon dioxide $\left(p \mathrm{CO}_{2}\right)$ values were calculated by the geochemical computer code PHREEQC (Parkhurst and Appelo, 2004). The $p \mathrm{CO}_{2}$ values of groundwater range from $10^{-0.82}$ to $10^{-4.1} \mathrm{~atm}$. The vast majority of groundwater samples (about $96 \%$ ) have higher $p \mathrm{CO}_{2}$ values than the atmospheric $p \mathrm{CO}_{2}$, which is equal to $10^{-3.5} \mathrm{~atm}$ (Van der Weijden and Pacheco, 2003), indicating that groundwater has received $\mathrm{CO}_{2}$ from root respiration and the decomposition of soil organic matter. Figure 9 indicates that the $p \mathrm{CO}_{2}$ values are negatively correlated with $\mathrm{pH}$ values; the partial pressure values of $\mathrm{CO}_{2}$ decrease as $\mathrm{pH}$ values increase (Rightmire, 1978; Adams et al., 2001). It likely has a connection with relatively longer aquifer residence time, more physical, chemical reactions with aquifer minerals and biological reactions of microorganism that produce $\mathrm{CO}_{2}$ taking place. According to Hou et al. (2008), feldspars can be observed in the Cretaceous formations and it is possible that the following reaction occurs:

$$
\begin{array}{r}
\mathrm{Na}_{2} \mathrm{Al}_{2} \mathrm{Si}_{6} \mathrm{O}_{16}+2 \mathrm{H}_{2} \mathrm{O}+\mathrm{CO}_{2} \rightarrow \mathrm{Na}_{2} \mathrm{CO}_{3} \\
+\mathrm{H}_{2} \mathrm{Al}_{2} \mathrm{Si}_{2} \mathrm{O}_{8}+\mathrm{H}_{2} \mathrm{O}+4 \mathrm{SiO}_{2} .
\end{array}
$$

This reaction will consume $\mathrm{CO}_{2}$ and give rise to the increase of the concentration of $\mathrm{Na}^{+}$and $\mathrm{HCO}_{3}^{-}$. As a result, the partial pressure of $\mathrm{CO}_{2}$ will decrease and the $\mathrm{pH}$ will increase. In terms of a statistical analysis, the average $\mathrm{pH}$ values of the
Quaternary groundwater and the shallow Cretaceous groundwater are 8.08 and 7.99 , respectively, lower than that of the deep Cretaceous groundwater (8.11). However, the average $p \mathrm{CO}_{2}$ values of the Quaternary groundwater and the shallow Cretaceous groundwater are $10^{-2.67}$ and $10^{-2.58} \mathrm{~atm}$, respectively, higher than that of the deep Cretaceous groundwater (about $10^{-2.79} \mathrm{~atm}$ ). The negative correlation characteristic between $p \mathrm{CO}_{2}$ and $\mathrm{pH}$ shows that the dissolution of feldspar takes place along groundwater flow path. The phenomenon also occurs in the Habor Lake basin according to Yin et al. (2009).

Cation exchange is an important process of water-rock interactions that obviously influences the major ion composition of groundwater (Xiao et al., 2012). Although the cation exchange is widespread in the geochemical evolution of all groundwater, it is essential to know and identify the various changes undergone by water during their traveling processes in the groundwater system under the influence of anthropogenic activities. In the present study, the molar $\mathrm{Na} / \mathrm{Ca}$ ratio changes between 0.5 and 106.09 with an average of 3.80, suggesting the presence of $\mathrm{Na}^{+}$and $\mathrm{Ca}^{2+}$ exchange. It can be conveyed in the following reaction:

$\mathrm{Ca}^{2+}+\mathrm{Na}_{2}-X=2 \mathrm{Na}^{+}+\mathrm{Ca}-X$,

where $X$ is sites of cation exchange.

Schoeller proposed that chloro-alkaline indices could be used to study the cation exchange between the groundwater and its host environment during residence or travel (Schoeller, 1965; Marghade et al., 2012; Li et al., 2013). The Schoeller indices, such as CAI-I and CAI-II, are calculated by the following equations, where all ions are expressed in $\mathrm{mEqL} \mathrm{L}^{-1}$ :

$$
\begin{aligned}
& \mathrm{CAI}-\mathrm{I}=\frac{\mathrm{Cl}^{-}-\left(\mathrm{Na}^{+}+\mathrm{K}^{+}\right)}{\mathrm{Cl}^{-}}, \\
& \mathrm{CAI}-\mathrm{II}=\frac{\mathrm{Cl}^{-}-\left(\mathrm{Na}^{+}+\mathrm{K}^{+}\right)}{\mathrm{HCO}_{3}^{-}+\mathrm{SO}_{4}^{2-}+\mathrm{CO}_{3}^{2-}+\mathrm{NO}_{3}^{-}} .
\end{aligned}
$$

When the Schoeller indices are negative, an exchange of $\mathrm{Ca}^{2+}$ or $\mathrm{Mg}^{2+}$ in groundwater with $\mathrm{Na}^{+}$or $\mathrm{K}^{+}$in aquifer materials takes place, $\mathrm{Ca}^{2+}$ or $\mathrm{Mg}^{2+}$ will be removed from solution and $\mathrm{Na}^{+}$or $\mathrm{K}^{+}$will be released into the groundwater. At the same time, negative value indicates chloroalkaline disequilibrium and the reaction is known as cationanion exchange reaction. During this process, the host rocks are the primary sources of dissolved solids in the water. In another case, if the positive values are obtained, then the inverse reaction possibly occurs and it is known as base exchange reaction. In the present study, almost all groundwater samples had negative Schoeller index values (Table S1), which indicates cation-anion exchange (chloro-alkaline disequilibrium). The results indeed clearly show that $\mathrm{Na}^{+}$and $\mathrm{K}^{+}$are released by the $\mathrm{Ca}^{2+}$ and $\mathrm{Mg}^{2+}$ exchange, which is 
Table 2. Correlation coefficient of major parameters in groundwater.

\begin{tabular}{|c|c|c|c|c|c|c|c|c|c|}
\hline & $\mathrm{K}^{+}$ & $\mathrm{Na}^{+}$ & $\mathrm{Ca}^{2+}$ & $\mathrm{Mg}^{2+}$ & $\mathrm{Cl}^{-}$ & $\mathrm{SO}_{4}^{2-}$ & $\mathrm{HCO}_{3}^{-}$ & TDS & $\mathrm{pH}$ \\
\hline $\mathrm{K}^{+}$ & 1.000 & 0.538 & 0.309 & 0.560 & 0.553 & 0.300 & 0.572 & 0.534 & -0.063 \\
\hline $\mathrm{Na}^{+}$ & & 1.000 & 0.217 & 0.651 & 0.824 & 0.485 & 0.602 & 0.728 & -0.072 \\
\hline $\mathrm{Ca}^{2+}$ & & & 1.000 & 0.754 & 0.375 & 0.665 & 0.478 & 0.796 & -0.600 \\
\hline $\mathrm{Mg}^{2+}$ & & & & 1.000 & 0.655 & 0.819 & 0.582 & 0.939 & -0.382 \\
\hline $\mathrm{Cl}^{-}$ & & & & & 1.000 & 0.375 & 0.576 & 0.776 & -0.144 \\
\hline $\mathrm{SO}_{4}^{2-}$ & & & & & & 1.000 & 0.160 & 0.770 & -0.226 \\
\hline $\mathrm{HCO}_{3}^{-}$ & & & & & & & 1.000 & 0.625 & -0.398 \\
\hline TDS & & & & & & & & 1.000 & -0.378 \\
\hline $\mathrm{pH}$ & & & & & & & & & 1.000 \\
\hline
\end{tabular}
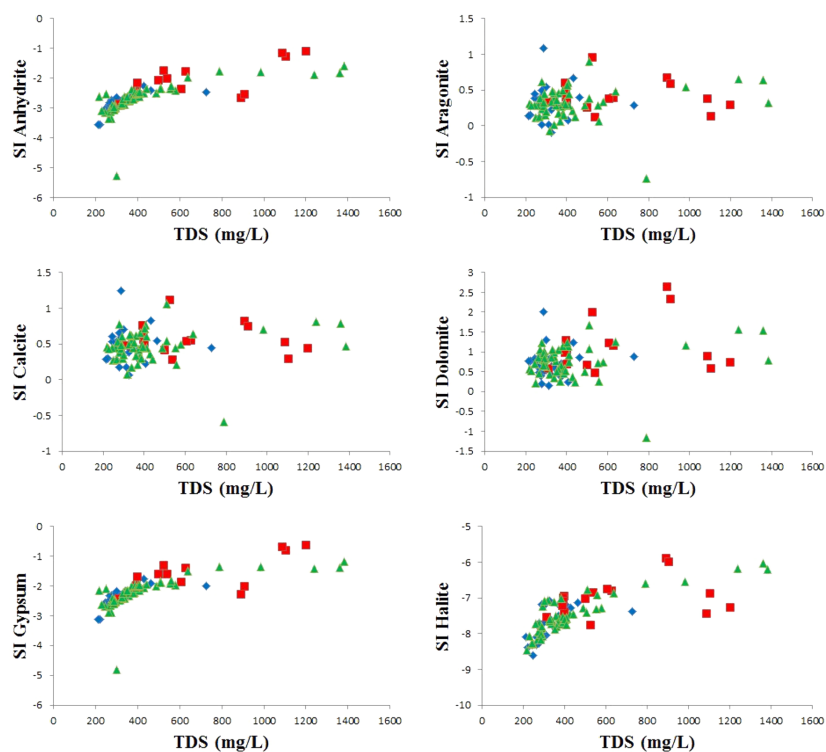

- Deep Cretaceous Groundwater

Legend: Quaternary Groundwater

A Shallow Cretaceous Groundwater

Figure 10. Plots of saturation indices with respect to some minerals in groundwater.

a common form of cation exchange in the study area. This also further confirms that the cation exchange is one of the major contributors to higher concentrations of $\mathrm{Na}^{+}$in the groundwater, and it is still an important geochemical process of groundwater in the Subei Lake basin under the influence of human activities.

\subsection{The formation mechanisms of groundwater and surface water}

The saturation index is a vital geochemical parameter in the fields of hydrogeology and geochemistry, often useful for identifying the existence of some common minerals in the groundwater system (Deutsch, 1997). In this present study, saturation indices (SIs) with respect to gypsum, anhydrite, calcite, dolomite, aragonite and halite were calculated in terms of the following equation (Lloyd and Heathcote, 1985):

$\mathrm{SI}=\log \left(\frac{\mathrm{IAP}}{k_{\mathrm{S}}(T)}\right)$

where IAP is the relevant ion activity product, which can be calculated by multiplying the ion activity coefficient $\gamma_{\mathrm{i}}$ and the composition concentration $m_{\mathrm{i}}$, and $k_{\mathrm{s}}(T)$ is the equilibrium constant of the reaction considered at the sample temperature. The geochemical computer model PHREEQC (Parkhurst and Appelo, 2004) was used to calculate the saturation indices. When the groundwater is saturated with some minerals, SI equals zero; positive values of SI represent oversaturation, and negative values show undersaturation (Appelo and Postma, 1994; Drever, 1997).

Figure 10 indicates the plots of SI versus the total dissolved solids (TDS) for all the groundwater samples. The calculated values of SI for anhydrite, gypsum and halite oscillate between -5.27 and -1.11 , between -4.8 and -0.65 and between -8.61 and -5.9 , with averages of $-2.62,-2.16$ and -7.49 , respectively. It shows that the groundwater in the study area was below the equilibrium with anhydrite, gypsum and halite, indicating that these minerals are anticipated to dissolve. However, the SIs of aragonite, calcite, and dolomite range from -0.74 to $1.09,-0.59$ to 1.25 and -1.16 to 2.64 , with averages of $0.32,0.48$ and 0.81 , respectively. On the whole, the groundwater samples were dynamically saturated to oversaturated with aragonite, calcite and dolomite, implying that the three major carbonate minerals may have affected the chemical composition of groundwater in the Subei Lake basin. The results show that the groundwater may well produce the precipitation of aragonite, calcite and dolomite. Saturation of aragonite, calcite and dolomite could be attained quickly due to the existence of abundant carbonate minerals in the groundwater system.

The soluble ions in natural waters mainly derive from rock and soil weathering (Lasaga et al., 1994), anthropogenic input and partly from the precipitation input. In order to make an analysis of the formation mechanisms of hydrochemistry, 


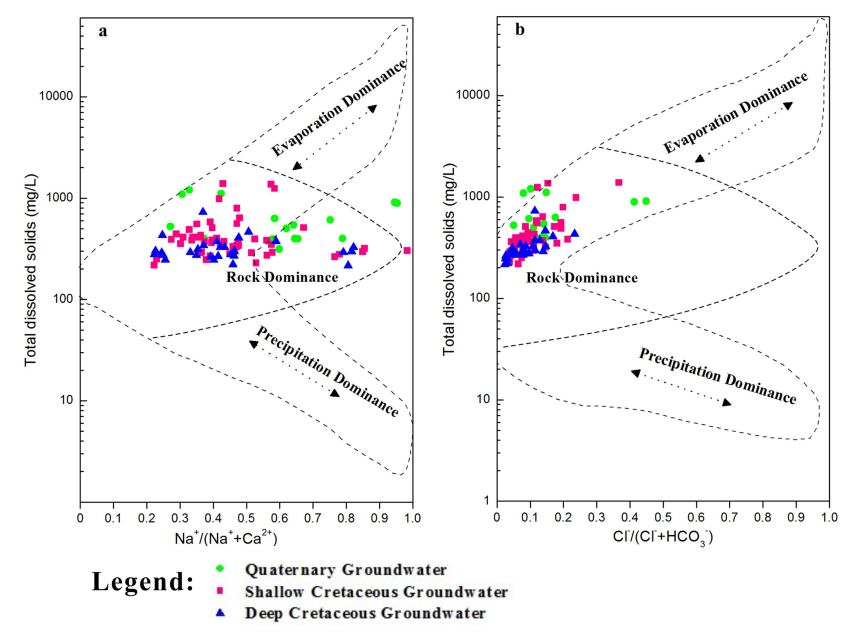

Figure 11. Gibbs diagram of groundwater samples in the Subei Lake basin: (a) TDS vs. $\mathrm{Na}^{+} /\left(\mathrm{Na}^{+}+\mathrm{Ca}^{2+}\right)$, (b) TDS vs. $\mathrm{Cl}^{-} /\left(\mathrm{Cl}^{-}+\mathrm{HCO}_{3}^{-}\right)$.

Gibbs diagrams have been widely used in hydrogeochemical studies (Feth and Gibbs, 1971; Naseem et al., 2010; Marghade et al., 2012; Yang et al., 2012b; Xing et al., 2013). Gibbs (1970) recommended two diagrams to assess the dominant effects of precipitation, rock weathering and evaporation on geochemical evolution of groundwater in semi-arid and arid regions. The diagrams show the weight ratios of $\mathrm{Na}^{+} /\left(\mathrm{Na}^{+}+\mathrm{Ca}^{2+}\right)$ and $\mathrm{Cl}^{-} /\left(\mathrm{Cl}^{-}+\mathrm{HCO}_{3}^{-}\right)$against TDS, and precipitation dominance, rock dominance, and evaporation dominance are included in the controlling mechanisms (Gibbs, 1970). The distributed characteristic of samples in Fig. 11 shows that rock weathering is the dominant mechanism in the geochemical evolution of the groundwater in the study area. The ratio of $\mathrm{Na}^{+} /\left(\mathrm{Na}^{+}+\mathrm{Ca}^{2+}\right)$ was mostly less than 0.5 in shallow and deep Cretaceous groundwater, with low TDS values (Fig. 11). It shows that rock weathering was the main mechanism controlling the chemical compositions of shallow and deep Cretaceous groundwater. In the Quaternary groundwater, about two-thirds of samples had a ratio of $\mathrm{Na}^{+} /\left(\mathrm{Na}^{+}+\mathrm{Ca}^{2+}\right)$ greater than 0.5 and higher TDS between 314 and $1202 \mathrm{mg} / \mathrm{L}$, which indicated that the Quaternary groundwater was not only controlled by rock weathering, but also by the process of evaporation-crystallization. It is obvious that the weight ratio of $\mathrm{Na}^{+} /\left(\mathrm{Na}^{+}+\mathrm{Ca}^{2+}\right)$ spreads from low to high without a great variation of TDS, which indicated that cation exchange also played a role by increasing $\mathrm{Na}^{+}$and decreasing $\mathrm{Ca}^{2+}$ under the background of rock dominance. During the cation exchange process, the TDS values do not change obviously because $2 \mathrm{mmol} \mathrm{L}^{-1}$ of $\mathrm{Na}^{+}$is released by $1 \mathrm{mmol} \mathrm{L}^{-1} \mathrm{Ca}^{2+}$ exchange, and the weight of $1 \mathrm{mmol} \mathrm{L}^{-1}$ of $\mathrm{Ca}^{2+}\left(40 \mathrm{mg} \mathrm{L}^{-1}\right)$ is nearly equal to that of $2 \mathrm{mmol} \mathrm{L}^{-1}$ of $\mathrm{Na}^{+}\left(46 \mathrm{mg} \mathrm{L}^{-1}\right)$.

In August, the average isotopic values of deep Cretaceous groundwater $\left(\delta^{18} \mathrm{O}:-8.4 \%\right.$ o, $\delta \mathrm{D}:-67 \%$ ) were enriched compared with the Quaternary groundwater $\left(\delta^{18} \mathrm{O}:-8.8 \%\right.$, $\delta \mathrm{D}:-71 \%$ ) , but in December, the average isotopic values of deep Cretaceous groundwater $\left(\delta^{18} \mathrm{O}:-8.5 \%\right.$ o, $\delta \mathrm{D}:-66 \%$ ) were depleted compared with the Quaternary groundwater $\left(\delta^{18} \mathrm{O}:-8.2 \%, \delta \mathrm{D}:-65 \%\right)$; the stable isotopic values of Quaternary groundwater had a wider range from August to December than those of deep Cretaceous groundwater. This may be explained by heavy isotope enrichment in the Quaternary groundwater caused by evaporation given that there was effectively no precipitation in the study area during the period from August to December; meanwhile, the deep Cretaceous groundwater may have been mainly recharged by lateral inflow from groundwater outside the study area, resulting in smaller seasonal fluctuations in the isotopic values.

Furthermore, the average values of $\delta^{18} \mathrm{O}$ and $\delta \mathrm{D}$ of the shallow Cretaceous groundwater are -8.3 and $-66 \%$ and -8.2 and $-64 \%$, respectively, in August and December; meanwhile, the average values of $\delta^{18} \mathrm{O}$ and $\delta \mathrm{D}$ of the deep Cretaceous groundwater are -8.4 and $-67 \%$ and -8.5 and $-66 \%$, respectively, in August and December. Thus, given the precision of the analysis, shallow Cretaceous groundwater and deep Cretaceous groundwater have similar isotopic characteristics in the Subei Lake basin, which indicates that they may be replenished by the similar water source due to the similar geological setting. This also validates the existence of leakage. The similar isotopic characteristic of groundwater from the Cretaceous aquifer may be ascribed to the increasingly close relationship between shallow Cretaceous groundwater and deep Cretaceous groundwater due to changes in the hydrodynamic field caused by intensive groundwater exploitation. Conversely, the phenomenon of deep groundwater depleted in heavy isotopes compared with shallow groundwater was found in the Habor Lake basin located in the recharge area (Yin et al., 2009).

The hydrogen and oxygen isotopes signatures in lake water show that it contains abnormally high levels of heavy isotopic composition. Compared with the stable isotopic values in groundwater, it is evident that lake water has undergone a greater degree of enrichment in heavy isotopes, which further illustrates that fractionation by strong evaporation is occurring predominantly in the lake water. This also proves to be in accordance with the unique hydrochemical characteristics of the lake water. In addition, the slope and intercept of the regression line for $\delta^{18} \mathrm{O}$ and $\delta \mathrm{D}$ in lake water were 1.47 and -29.09 , lower than the slope and intercept $(7.51,-7.12)$ observed for lake water in the Habor Lake basin (Yin et al., 2009). By comparison, it is clearly confirmed that lake water in the discharge area has undergone stronger evaporation than lake water in the recharge area. As a result, lake water in the Subei Lake basin contains more heavily isotopic composition than that in the Habor Lake basin. 


\section{Conclusions}

The present study examines the hydrochemical and isotopic composition of the groundwater and surface water in the Subei Lake basin with various methods such as correlation analysis, saturation index, Piper diagram and Gibbs diagrams. The combination of major elements geochemistry and stable isotopes $\left(\delta^{18} \mathrm{O}, \delta \mathrm{D}\right)$ has provided a comprehensive understanding of the hydrodynamic functioning and the processes of mineralization that underpin the geochemical evolution of the whole water system. The hydrochemical data show that three groups of groundwater are present in the Subei Lake basin: the Quaternary groundwater, shallow Cretaceous groundwater and deep Cretaceous groundwater. The analysis of groundwater chemistry clarifies that the chemistry of lake water was controlled by strong evaporation and recharge from overland flow and groundwater; meanwhile the major geochemical processes responsible for the observed chemical composition in groundwater are the dissolution/precipitation of anhydrite, gypsum, halite and calcite and the weathering of feldspar and dolomite. Furthermore, the cation exchange has also played an extremely vital role in the groundwater evolution. The absolute predominance of rock weathering in the geochemical evolution of groundwater in the study area is confirmed by the analytical results of Gibbs diagrams. The stable isotopic data indicate that groundwater is of modern local meteoric origin rather than the recharge from precipitation in paleoclimate conditions. Unlike significant differences in isotopic values between shallow groundwater and deep groundwater in the Habor Lake basin, shallow Cretaceous groundwater and deep Cretaceous groundwater have similar isotopic characteristics in the Subei Lake basin. Due to the evaporation effect and dry climatic conditions, heavy isotopes are more enriched in lake water than groundwater. The low slope of the regression line of $\delta^{18} \mathrm{O}$ and $\delta \mathrm{D}$ in lake water could be ascribed to a combination of mixing and evaporation under conditions of low humidity. A comparison of the regression line for $\delta^{18} \mathrm{O}$ and $\delta \mathrm{D}$ shows that lake water in the Subei Lake basin contains more heavily isotopic composition than that in the Habor Lake basin, indicating that lake water in the discharge area has undergone stronger evaporation than lake water in the recharge area.

Much more accurate groundwater information has been obtained by conducting this study on Subei Lake basin, which will further enhance the knowledge of geochemical evolution of the groundwater system in the whole Ordos Basin and provide comprehensive understanding of Subei Lake basin, typical of lake basins in the discharge area where significant changes in the groundwater system have taken place under the influence of human activity. More importantly, it could provide valuable groundwater information for decision makers and researchers to formulate scientifically reasonable groundwater resource management strategies in these lake basins of Ordos Basin so as to minimize the nega- tive impacts of anthropogenic activities on the water system. In addition, given that there have been a series of ecological and environmental problems, more ecohydrological studies in these lake basins are urgently needed from the perspective of the future sustainable development of natural resources.

\section{The Supplement related to this article is available online at doi:10.5194/hess-12-551-2015-supplement.}

Acknowledgements. This research was supported by the State Basic Research Development Program (973 Program) of China (grant no. 2010CB428805) and Greenpeace International. The authors are grateful for our colleagues for their assistance in sample collection and analysis. Special thanks go to the editor and the two anonymous reviewers for their critical reviews and valuable suggestions.

Edited by: S. Uhlenbrook

\section{References}

Adams, S., Titus, R., Pietersen, K., Tredoux, G., and Harris, C.: Hydrochemical characteristics of aquifers near Sutherland in the Western Karoo, South Africa, J. Hydrol., 241, 91-103, doi:10.1016/S0022-1694(00)00370-X, 2001.

Agartan, E. and Yazicigil, H.: Assessment of water supply impacts for a mine site in western Turkey, Mine Water Environ., 31, 112128, doi:10.1007/s10230-011-0167-z, 2012.

Appelo, C. A. J. and Postma, D.: Geochemistry, groundwater and pollution, AA Balkema, Rotterdam, 1994.

Appelo, C. A. J. and Willemsen, A.: Geochemical calculations and observations on salt water intrusions, I. A combined geochemical/mixing cell model, J. Hydrol., 94, 313-330, 1987.

Cervi, F., Ronchetti, F., Martinelli, G., Bogaard, T. A., and Corsini, A.: Origin and assessment of deep groundwater inflow in the $\mathrm{Ca}$ Lita landslide using hydrochemistry and in situ monitoring, Hydrol. Earth Syst. Sci., 16, 4205-4221, doi:10.5194/hess-16-42052012, 2012.

Chen, J., Liu, X., Wang, C., Rao, W., Tan, H., Dong, H., Sun, X., Wang, Y., and Su, Z.: Isotopic constraints on the origin of groundwater in the Ordos Basin of northern China, Environ. Earth Sci., 66, 505-517, doi:10.1007/s12665-011-1259-6, 2011.

Clark, I. D. and Fritz, P.: Environmental isotopes in hydrogeology, CRC press, Boca Raton, Florida, 1997.

Cook, P. G. and Herczeg, A. L.: Environmental tracers in subsurface hydrology, Kluwer, Dordrecht, 1999.

Craig, H.: Isotopic variations in meteoric waters, Science, 133, 1702-1703, doi:10.1126/science.133.3465.1702, 1961.

Dai, S. F., Ren, D. Y., Chou, C. L., Li, S. S., and Jiang, Y. F.: Mineralogy and geochemistry of the No. 6 coal (Pennsylvanian) in the Junger Coalfield, Ordos Basin, China, Int. J. Coal Geol., 66, 253-270, doi:10.1016/j.coal.2005.08.003, 2006.

Deutsch, W. J.: Groundwater geochemistry: fundamentals and applications to contamination, CRC press, Boca Raton, Florida, 1997. 
De Vries, J. J. and Simmers, I.: Groundwater recharge: an overview of processes and challenges, Hydrogeol. J., 10, 5-17, doi:10.1007/s10040-001-0171-7, 2002.

Dixon, W. and Chiswell, B.: The use of hydrochemical sections to identify recharge areas and saline intrusions in alluvial aquifers, southeast Queensland, Australia, J. Hydrol., 135, 259274, doi:10.1016/0022-1694(92)90091-9, 1992.

Drever, J. I.: The geochemistry of natural waters: surface and groundwater environments, Prentice Hall, New Jersey, 1997.

Feth, J. H. and Gibbs, R. J.: Mechanisms controlling world water chemistry: evaporation-crystallization process, Science, 172, 871-872, 1971.

Garvelmann, J., Külls, C., and Weiler, M.: A porewater-based stable isotope approach for the investigation of subsurface hydrological processes, Hydrol. Earth Syst. Sci., 16, 631-640, doi:10.5194/hess-16-631-2012, 2012.

Gibbs, R. J.: Mechanisms controlling world water chemistry, Science, 170, 1088-1090, doi:10.1126/science.170.3962.1088, 1970.

Hamed, Y. and Dhahri, F.: Hydro-geochemical and isotopic composition of groundwater, with emphasis on sources of salinity, in the aquifer system in Northwestern Tunisia, J. Afr. Earth Sci., 83, 10-24, doi:10.1016/j.jafrearsci.2013.02.004, 2013.

Hou, G., Zhao, M., and Wang, Y.: Groundwater investigation in the Ordos Basin, China Geological Survey, Beijing, 2006 (in Chinese).

Hou, G., Su, X., Lin, X., Liu, F., Yi, S., Dong, W., Yu, F., Yang, Y., and Wang, D.: Environmental isotopic composition of natural water in Ordos Cretaceous Groundwater Basin and its significance for hydrological cycle, J. Jilin Univ. (Earth Science Edition), 37, 255-260, 2007.

Hou, G., Liang, Y., Su, X., Zhao, Z., Tao, Z., Yin, L., Yang, Y., and Wang, X.: Groundwater systems and resources in the Ordos Basin, China, Acta Geol. Sin., 82, 1061-1069, 2008.

Kamdee, K., Srisuk, K., Lorphensri, O., Chitradon, R., Noipow, N., Laoharojanaphand, S., and Chantarachot, W.: Use of isotope hydrology for groundwater resources study in Upper Chi river basin, J. Radioanal. Nuclear Chem., 297, 405-418, doi:10.1007/s10967-012-2401-y, 2013.

Lasaga, A. C., Soler, J. M., Ganor, J., Burch, T. E., and Nagy, K. L.: Chemical-weathering rate laws and global geochemical cycles, Geochim. Cosmochim. Ac., 58, 2361-2386, doi:10.1016/00167037(94)90016-7, 1994.

Li, P., Wu, J., and Qian, H.: Groundwater quality assessment and the forming mechanism of the hydrochemistry in Dongsheng Coalfield of Inner Mongolia, J. Water Resour. Water Eng., 21, 38-41, 2010 (in Chinese).

Li, P., Qian, H., and Wu, J. H.: Application of set pair analysis method based on entropy weight in groundwater quality assessment - a case study in Dongsheng City, Northwest China, E-J Chem., 8, 851-858, 2011.

Li, P., Qian, H., Wu, J., Zhang, Y., and Zhang, H.: Major ion chemistry of shallow groundwater in the Dongsheng Coalfield, Ordos Basin, China, Mine Water Environ., 32, 195-206, doi:10.1007/s10230-013-0234-8, 2013.

Lloyd, J. W. and Heathcote, J.: Natural inorganic hydrochemistry in relation to groundwater, Oxford University Press, New York, 1985.
Magaritz, M., Nadler, A., Koyumdjisky, H., and Dan, J.: The use of $\mathrm{Na}-\mathrm{Cl}$ ratios to trace solute sources in a semi-arid zone, Water Resour. Res., 17, 602-608, doi:10.1029/Wr017i003p00602, 1981.

Marghade, D., Malpe, D. B., and Zade, A. B.: Major ion chemistry of shallow groundwater of a fast growing city of Central India, Environ. Monit. Assess., 184, 2405-2418, doi:10.1007/s10661011-2126-3, 2012.

Naseem, S., Rafique, T., Bashir, E., Bhanger, M. I., Laghari, A., and Usmani, T. H.: Lithological influences on occurrence of high-fluoride groundwater in Nagar Parkar area, Thar Desert, Pakistan, Chemosphere, 78, 1313-1321, doi:10.1016/j.chemosphere.2010.01.010, 2010.

Parkhurst, D. L. and Appelo, C.: PHREEQC2 user's manual and program, Water-Resources Investigations Report, US Geological Survey, Denver, Colorado, 2004.

Piper, A. M.: A graphic procedure in the geochemical interpretation of water analysis, US Department of the Interior, Geological Survey, Water Resources Division, Ground Water Branch, Washington, 1953.

PRC Ministry of Environmental Protection: Technical guidelines for environment impact assessment-groundwater environment, China Environmental Science Press,Beijing, 2011.

Rightmire, C. T.: Seasonal-variation in $\mathrm{pCO}_{2}$ and ${ }^{13} \mathrm{C}$ content of soil atmosphere, Water Resour. Res., 14, 691-692, doi:10.1029/Wr014i004p00691, 1978.

Sami, K.: Recharge mechanisms and geochemical processes in a semiarid sedimentary basin, Eastern Cape, South-Africa, J. Hydrol., 139, 27-48, doi:10.1016/0022-1694(92)90193-Y, 1992.

Schoeller, H.: Qualitative evaluation of groundwater resources, In: Methods and techniques of groundwater investigations and development, UNESCO, Paris, 54-83, 1965.

Su, Y., Zhu, G., Feng, Q., Li, Z., and Zhang, F.: Environmental isotopic and hydrochemical study of groundwater in the Ejina Basin, northwest China, Environ. Geol., 58, 601-614, doi:10.1007/s00254-008-1534-3, 2009.

Toth, J.: A theoretical analysis of groundwater flow in small drainage basins, J. Geophys. Res., 68, 4795-4812, doi:10.1029/Jz068i008p02354, 1963.

Van der Weijden, C. H., and Pacheco, F. A. L.: Hydrochemistry, weathering and weathering rates on Madeira island, J. Hydrol., 283, 122-145, doi:10.1016/S0022-1694(03)00245-2, 2003.

Wang, W., Yang, G., and Wang, G.: Groundwater numerical model of Haolebaoji well field and evaluation of the environmental problems caused by exploitation, South-to-North Water Trans. Water Sci. Technol., 8, 36-41, 2010 (in Chinese).

Winter, T. C.: Relation of streams, lakes, and wetlands to groundwater flow systems, Hydrogeol. J., 7, 28-45, doi:10.1007/s100400050178, 1999.

Xiao, J., Jin, Z., Zhang, F., and Wang, J.: Solute geochemistry and its sources of the groundwaters in the Qinghai Lake catchment, NW China, J. Asian Earth Sci., 52, 21-30, doi:10.1016/j.jseaes.2012.02.006, 2012.

Xing, L., Guo, H., and Zhan, Y.: Groundwater hydrochemical characteristics and processes along flow paths in the North China Plain, J. Asian Earth Sci., 70-71, 250-264, doi:10.1016/j.jseaes.2013.03.017, 2013. 
Yang, L., Song, X., Zhang, Y., Han, D., Zhang, B., and Long, D.: Characterizing interactions between surface water and groundwater in the Jialu River basin using major ion chemistry and stable isotopes, Hydrol. Earth Syst. Sci., 16, 4265-4277, doi:10.5194/hess-16-4265-2012, 2012a.

Yang, L., Song, X., Zhang, Y., Yuan, R., Ma, Y., Han, D., and $\mathrm{Bu}, \mathrm{H} .:$ A hydrochemical framework and water quality assessment of river water in the upper reaches of the Huai River Basin, China, Environ. Earth Sci., 67, 2141-2153, doi:10.1007/s12665012-1654-7, 2012b.

Yin, L., Hou, G., Dou, Y., Tao, Z., and Li, Y.: Hydrogeochemical and isotopic study of groundwater in the Habor Lake Basin of the Ordos Plateau, NW China, Environ. Earth Sci., 64, 1575-1584, doi:10.1007/s12665-009-0383-z, 2009.
Yin, L., Hou, G., Su, X., Wang, D., Dong, J., Hao, Y., and Wang, X.: Isotopes $\left(\delta \mathrm{D}\right.$ and $\left.\delta^{18} \mathrm{O}\right)$ in precipitation, groundwater and surface water in the Ordos Plateau, China: implications with respect to groundwater recharge and circulation, Hydrogeol. J., 19, 429443, doi:10.1007/s10040-010-0671-4, 2010.

Yuko, A., Uchida, T., and Ohte, N.: Residence times and flow paths of water in steep unchannelled catchments, Tanakami, Japan, J. Hydrol., 261, 173-192, 2002.

Zhang, J., Fang, H., and Ran, G.: Groundwater resources assessment in the Ordos Cretaceous Artesian Basin, Inner Mongolia Bureau of Geology and Mineral Resources, Hohhot, 1986. 